\title{
EVIDENCE OF THE SUPERPRODUCTION OF THE CONTINENTAL CRUST DURING PALEOPROTEROZOIC IN SOUTH AMERICAN PLATFORM. IMPLICATIONS REGARDING THE INTERPRETATIVE VALUE OF THE SM-ND MODEL AGES
}

\section{KEI SATO AND OSWALDO SIGA JÚNIOR}

\begin{abstract}
The production of juvenile continental crust was larger in the Proterozoic than Archean. During Proterozoic the production was about $64 \%$, while during Archean was around $34 \%$ of the total volume. The great accretion from mantle to crust happened between 2,2 to $1,9 \mathrm{Ga}$ corresponding $35 \%$ of the total volume of the actual continental crust. During Archean an intense recycling between mantle and continental crust took place, while in Paleoproterozoic the rate of mantle accretion to continental crust was larger than the assimilation. During MesoNeoproterozoic little accretion of juvenile material occurred, predominating crustal reworking. Consequently the chemical depletion rate (fractionation) of the upper mantle was smaller in Archean than Proterozoic. The isotopic data show a certain increase of the depletion degree of $\mathrm{Sm}-\mathrm{Nd}$ and $\mathrm{Rb}-\mathrm{Sr}$ in the upper mantle that began at $2.2 \mathrm{Ga}$ as a reflex of the strong differentiation of the upper mantle to continental crust.
\end{abstract}

Keywords: Paleoproterozoic material accretion, South American Platform, Sm-Nd model age.

INTRODUCTION Sm-Nd model ages refer to the time when crustal material differentiated from upper mantle through convection. The uncertainties come from a lack of adequate information on crustal processes and the variable composition and mantle source type. This paper discuss crustal and upper mantle evolution from South American Platform and the implications regarding the interpretative value of the model ages, $\mathrm{T}_{\mathrm{DM}}$ and $\mathrm{T}_{\mathrm{CHUR}}$, based on the $\mathrm{Sm}-\mathrm{Nd}$ data presented by Sato (1998), Sato (1999), Sato \& Cordani (1999) and Sato \& Siga Jr (2000).

\section{EVIDENCE OF THE SUPERPRODUTION OF THE CONTI-} NENTAL CRUST DURING MIDDLE PALEOPROTEROZOIC In the South American Platform small proportion of continental crust older than $3.3 \mathrm{Ga}$ are preserved, as in any of the continental areas of the world. The continental crust preserved during the Archean was about $34 \%$ of the current volume (Fig. 1). The total amount of juvenile material accreted during the Paleoproterozoic was about 54\%, while during Meso-Neoproterozoic about $10 \%$ and the remaining $1 \%$ in the Phanerozoic. Therefore, the juvenile accretion during Proterozoic was
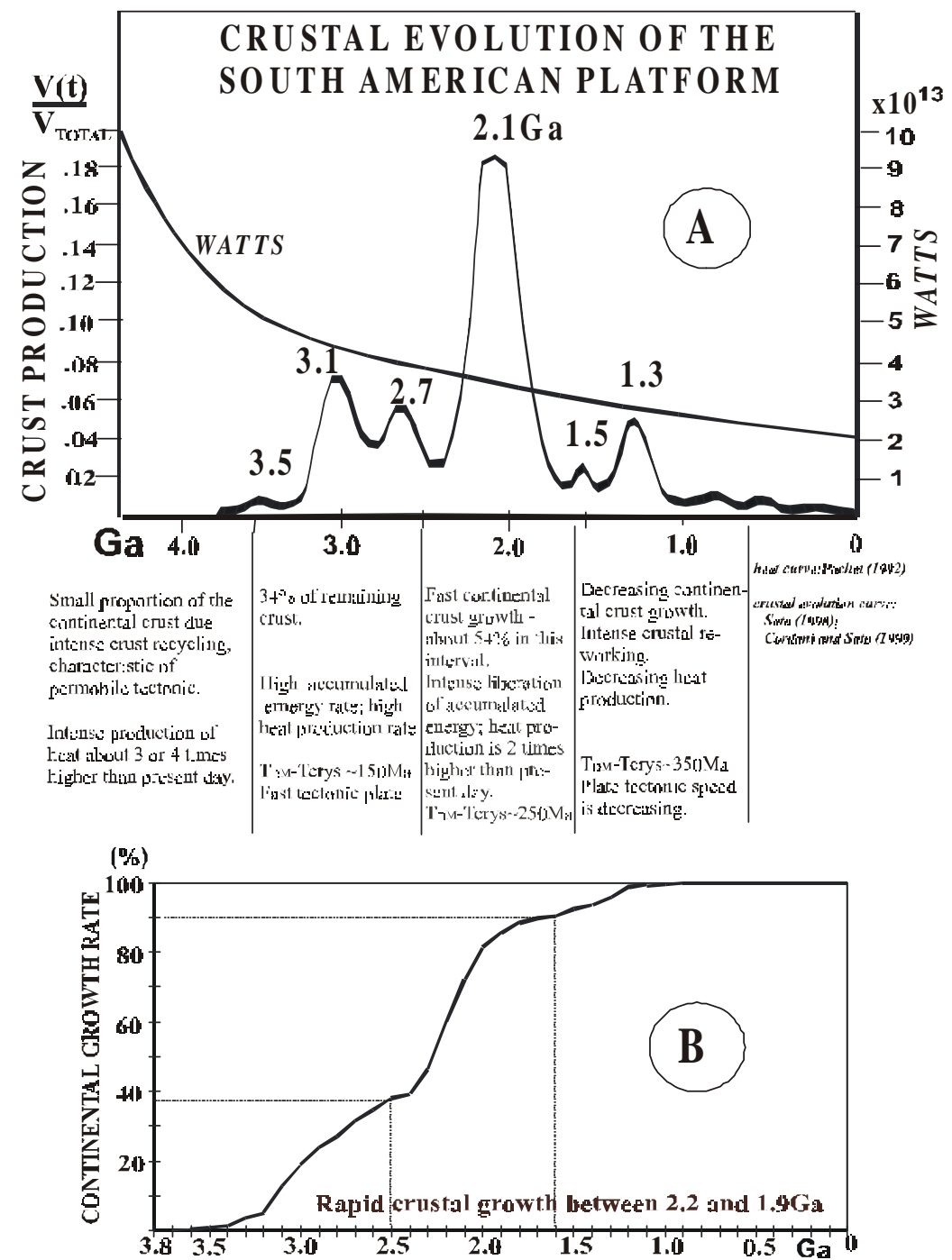

Figure 1 - Superproduction of continental crust during Paleoproterozoic in the South American Platform. (A) - Crustal evolution of the South American Platform with base in Sm-Nd model age; (B) - cumulative curve of the crust production versus geological time (Sato 1998, Cordani and Sato 1999). 


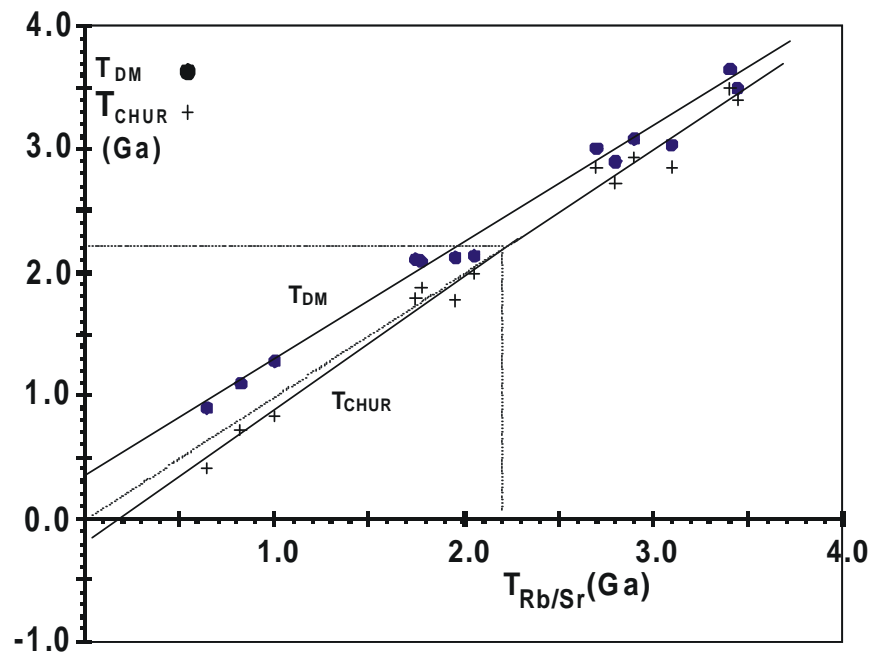

Figure $2-T_{R b-S r} X T_{D M}$ and $T_{R b-S r} X T_{C H U R}$ Diagram. Selected granitoid rocks of South American Platform (the data are presented in the Table 1 ).

Table 1 - Sm-Nd model ages ( $T_{D M}$ and $\left.T_{C H U R}\right), R b-S r$ ages and $f_{S m-N d}$ of granitoid rocks (type TTGs) from South American Platform. Only granitoid rocks with $\Delta T\left(T_{D M}-T_{\text {cryst }}\right)<0.3 G a$ and $\varepsilon_{N d}\left(T_{F}\right)>-2$ where $T_{F}$ is crystallization age have been selected. The $T_{D M}, T_{C H U R}, \varepsilon_{N d}\left(T_{F}\right)$ and $\varepsilon_{N d}(0)$ are mean values. Obs: $*=R b$-Sr age $; * *=U-P b(z$ ircão $)$ age.

\begin{tabular}{|c|c|c|c|c|c|c|c|}
\hline REGION & $\mathbf{T}_{\text {(Fomation) }}$ & $\mathbf{T}_{\mathrm{DM}}$ & $\mathbf{T}_{\mathrm{CHUR}}$ & $\mathbf{f}_{\mathrm{Sm} / \mathrm{Nd}}$ & $\varepsilon_{\mathrm{Nd}}(0)$ & $\varepsilon_{\mathrm{Nd}}\left(T_{F}\right)$ & ERA \\
\hline S.Voltas - S. Francisco Craton & $3,4 *$ & 3,65 & 3,5 & $-0,55$ & -49.1 & -2.2 & \multirow{6}{*}{ Archaean } \\
\hline B.Vista - S. Francisco Craton & $3,44^{*}$ & 3,5 & 3,4 & $-0,56$ & -49.2 & -0.3 & \\
\hline Cupixi - MIP - Amazonian Craton & $2,9 *$ & 3,08 & 2,93 & $-0,42$ & -42.2 & -0.9 & \\
\hline N. Eldorado- PAC - Amazonian Craton & $2,7^{*}$ & 3,0 & 2,86 & $-0,66$ & -43.8 & 2.95 & \\
\hline R. Maria- ACP - Amazonian Craton & $3,1 *$ & 3,04 & 2,86 & $-0,45$ & -32.8 & 2.4 & \\
\hline Taquarembo - Brazil South & $2,8 *$ & 2,9 & 2,73 & $-0,52$ & -36.2 & 0.5 & \\
\hline Tapajós- VTP - Amazonian Craton & $1,96^{*}$ & 2,12 & 1,77 & $-0,39$ & -17.1 & 1.7 & \multirow{4}{*}{$\begin{array}{c}\text { Paleo- } \\
\text { proterozoic }\end{array}$} \\
\hline N Manaus -VTP- Amazonian Craton & $1,78^{*}$ & 2,09 & 1,87 & $-0,64$ & -30.4 & -1.6 & \\
\hline N Manaus -VTP- Amazonian Craton & $1,75^{*}$ & 2,11 & 1,79 & $-0,43$ & -19.6 & -0.6 & \\
\hline Mansidão - S. Francisco Craton & $2,05^{*}$ & 2,14 & 2,0 & $-0,48$ & -22.6 & 2.2 & \\
\hline S.Gabriel - South Brazil & $0,65^{*}$ & 0,9 & 0,4 & $-0,45$ & -5.6 & 2.5 & \multirow{3}{*}{$\begin{array}{c}\text { Meso- } \\
\text { Neoprote- } \\
\text { rozoic }\end{array}$} \\
\hline Arenópolis - Central Goiás Complex & $0,82^{*}$ & 1,1 & 0,71 & $-0,5$ & -9.0 & 1.4 & \\
\hline S de L.Sienitóide-SPP- Borborema Prov. & $1,0^{\text {*** }}$ & 1,28 & 0,84 & $-0,46$ & -9.7 & -1.0 & \\
\hline
\end{tabular}

Table 2 - Diagram $T x \Delta T$ for the granitoid rocks where $\Delta T=T_{D M}-T_{R b-S r}$, $T_{C H U R}-T_{R b-S r}$ and $T_{D M}-T_{C H U R}$ (from figure 2 ). The column $T_{C H U R}-T_{R b-S r}$ show negative value starting at $2.2 \mathrm{Ga}$.

\begin{tabular}{|c|c|c|c|}
\hline $\begin{array}{c}\mathbf{T} \\
(\mathbf{G a})\end{array}$ & $\begin{array}{c}\mathbf{T}_{\text {DM}^{-}} \mathbf{-} \text { Rb-Sr } \\
(\mathbf{G a})\end{array}$ & $\begin{array}{c}\mathbf{T}_{\mathbf{C H U R}-\mathbf{T}_{\mathbf{R b}-S r}} \\
(\mathbf{G a})\end{array}$ & $\begin{array}{c}\mathbf{T}_{\text {DM }}-\mathbf{T}_{\mathbf{C H U R}} \\
(\mathbf{G a})\end{array}$ \\
\hline 3.5 & 0.15 & 0.06 & 0.09 \\
\hline 3.0 & 0.18 & 0.06 & 0.12 \\
\hline 2.5 & 0.21 & 0.05 & 0.16 \\
\hline 2.0 & 0.24 & -0.01 & 0.25 \\
\hline 1.5 & 0.26 & -0.06 & 0.32 \\
\hline 1.0 & 0.29 & -0.11 & 0.40 \\
\hline 0.5 & 0.32 & -0.15 & 0.45 \\
\hline 0.0 & 0.35 & -0.20 & 0.55 \\
\hline
\end{tabular}

higher than the Archean. For additional informations see Cordani and Sato (1999).

During Archean, possibly due to high temperature, an intense recycling of the continental crust has occurred. As a fundamental characteristic of this permobile tectonic regime, only 34\% of continental crust observed in the South American Platform was preserved. From 2.55 to $2.35 \mathrm{Ga}$ occurred a decreasing of the continental crust production and as consequence an intense energy accumulated. This energy was hindered to dissipate due to the tin sialic crust that consolidated previously. The rupture of this crust took place between 2.2 and $1.9 \mathrm{Ga}$ with intense energy dissipation, and the material was added from mantle to the continental crust as a superproduction about
$35 \%$ of the present volume during this short interval. The production of heat decreased during Meso-Neoproterozoic but it was high enough to move great plate units, metamorphosing and reworking crustal materials already formed.

Table $3-{ }^{143} \mathrm{Nd} /{ }^{144} \mathrm{Nd}$ ratios versus geological era. The estimated $\mathrm{Sm}-\mathrm{Nd}$ model ages (geological era) were calculated knowing only the ${ }^{143} \mathrm{Nd}{ }^{144} \mathrm{Nd}$ ratio.

\begin{tabular}{|l|l|l|}
\hline \multicolumn{1}{|c|}{${ }^{\mathbf{1 4 3}} \mathbf{N d} /{ }^{\mathbf{1 4 4}} \mathbf{N d}$} & \multicolumn{1}{|c|}{$\mathbf{E N d}(\mathbf{t}=\mathbf{0})$} & \multicolumn{1}{|c|}{ ERA } \\
\hline$<\sim 0.5113$ & $<\sim-24$ & Archean \\
$\sim 0.511$ to $\sim 0.5125$ & $\sim-24$ to $\sim-13$ & Paleoproterozoic \\
$>\sim 0.5122$ & $\sim-13$ to $\sim 0$ & Meso/Neoproterozoi \\
& & $\mathrm{c}$ \\
\hline
\end{tabular}

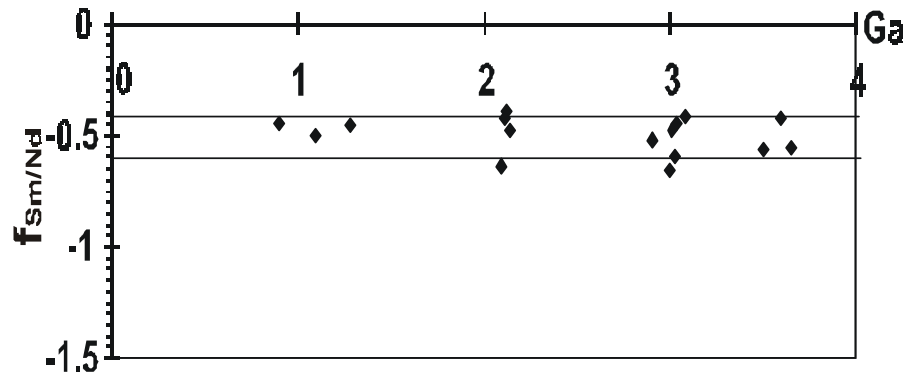

Figure 3 - $T_{D M} X f_{S m \backslash N d}$ diagram. The $f_{S m / N d}$ values in selected TTG type rocks, in general varied from $-0,60$ to $-0,40$ (table 1 ).

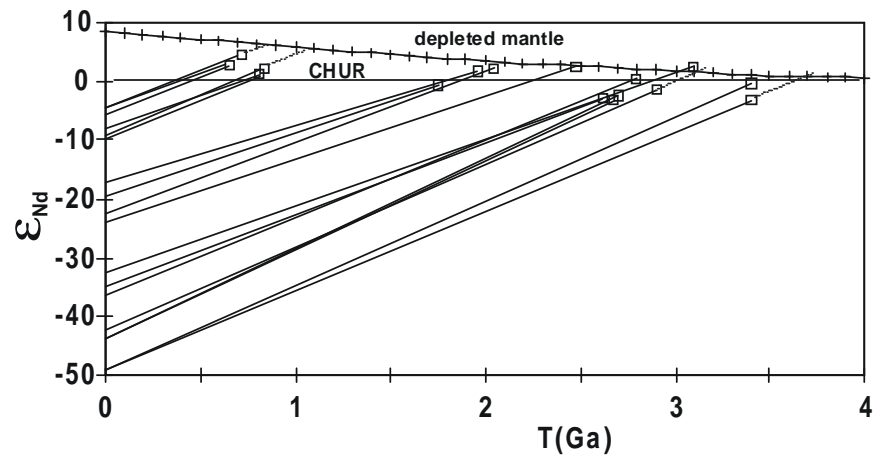

Figure $4-\varepsilon_{\mathrm{N} d} \times T(G a)$ Diagram. Nd isotopic evolution pattern of selected granitoid rocks, where $\Delta\left(T_{D M}-T_{\text {crystaliz }}\right)$ is $<0,30 G a$, to South American Platform (table 1). The square points refer $\mathrm{Rb}$-Sr ages.

\section{IMPLICATIONS REGARDING THE INTERPRETATIVE VALUE OF THE Sm -Nd MODEL AGES Strong depletion of the upper mantle in the middle Paleoproterozoic The}

$\mathrm{Rb}-\mathrm{Sr}$ ages and the $\mathrm{Sm}-\mathrm{Nd}$ model ages $\left(\mathrm{T}_{\mathrm{DM}}\right)$ in TTG rocks from the South American Platform show a systematic deviation and a correlation along geological time. Figure 2, shows the difference between accretion event $\left(\mathrm{T}_{\mathrm{DM}}\right)$ and rock formation age $\left(\mathrm{T}_{\mathrm{Rb}-\mathrm{Sr}}\right)$ decreasing with the geological time. The data used for the rock relation are presented in Table 1.

Based on the figure 2, the $\mathrm{T}_{\mathrm{DM}}$ and $\mathrm{T}_{\mathrm{CHUR}}$ model ages as a function of the crystallization age can be expressed by the following equations:

$$
\begin{aligned}
& \mathrm{T}_{\mathrm{DM}}=0.94 \mathrm{~T}_{\mathrm{Rb}-\mathrm{Sr}}+0.35 \rightarrow \text { f rom } 3.5 \text { to today } \\
& \mathrm{T}_{\mathrm{CHUR}} \cong \mathrm{T}_{\mathrm{Rb}-\mathrm{Sr}} \rightarrow \text { from } 4.5 \text { to } 2.2 \mathrm{Ga} \\
& \mathrm{T}_{\mathrm{CHUR}}=1.23 \mathrm{~T}_{\mathrm{Rb}-\mathrm{Sr}}-0.2 \rightarrow \text { from } 2.2 \text { to today }
\end{aligned}
$$

Considering that at $3,5 \mathrm{Ga}$ the $\Delta \mathrm{T}$ (where $\Delta \mathrm{T}=\mathrm{T}_{\mathrm{DM}}-\mathrm{T}_{\mathrm{Rb}-\mathrm{Sr}}$ ) was about $0.15 \mathrm{Ga}$ while in the present it is about $0.35 \mathrm{Ga}$ (from first equation and Table 2), it is suggested that the time interval between separation from upper mantle, where the chemical fractionation began, and the formation of the TTGs was faster in the Archean than the present. Such a difference can be explained by plate speeds, supposed 
Table 4 - Sm - Nd data in Minerals and $f_{S m-N d}$ fractionation factor. Ref.: Médio Coreau - Santos (1999).

\begin{tabular}{|c|c|c|c|c|c|c|}
\hline MINERAL & ROCK & LOCATION & $\begin{array}{c}\mathrm{Sm} \\
(\mathrm{ppm})\end{array}$ & $\begin{array}{c}\mathrm{Nd} \\
(\mathrm{ppm})\end{array}$ & $\begin{array}{l}{ }^{147} \mathrm{Sm} / \\
{ }^{144} \mathrm{Nd} \\
\end{array}$ & $\begin{array}{c}f_{S m / N} \\
d\end{array}$ \\
\hline \multirow{4}{*}{ Biotite } & Granulite & Itatins (SP) & 4.9 & 22.1 & .1341 & -.32 \\
\hline & Paragneiss & Itatins (SP) & 0.6 & 2.6 & .139 & -.29 \\
\hline & Gneiss & Piripa (Ba) & 2.454 & 15.04 & .0987 & -.50 \\
\hline & & Faure (1988) & 37.02 & 171.5 & .130 & -.34 \\
\hline \multirow{9}{*}{ Plagioclase } & Granulite & Itatins (SP) & 4.6 & 28.5 & .0976 & -.50 \\
\hline & Gneiss & Curitba (Pr) & -- & --- & .1079 & -.45 \\
\hline & Paragneiss & Itatins (SP) & 2.1 & 7.5 & .169 & -.14 \\
\hline & Gneiss & Médio Coreau & 0.65 & 6.51 & .0607 & -.69 \\
\hline & Amphibolit & São Roque & .49 & 2.66 & .112 & -.43 \\
\hline & $\begin{array}{l}\text { Amphibolit } \\
\mathrm{e}\end{array}$ & São Roque & .16 & 1.07 & .0901 & -.54 \\
\hline & Amphibolit & CPRM & 3.74 & 14.65 & .156 & -.20 \\
\hline & Gabbro & Beja, Portugal & 0.100 & 0.642 & .0942 & -.52 \\
\hline & & Faure $(19$ & 0.547 & 1.85 & .177 & -.10 \\
\hline \multirow{4}{*}{ Pyroxene } & Granulite & Itatins & 22.4 & 97.7 & .1386 & -.30 \\
\hline & & L. Alves (SC) & --- & --- & .1372 & -.30 \\
\hline & Gabbro & Beja/Portugal & 1.317 & 3.200 & .2488 & +.26 \\
\hline & & Faure (1988) & 3.34 & 9.09 & .222 & +.13 \\
\hline \multirow[t]{2}{*}{ K-Fedlsar } & Gneiss & Piripá & .809 & 5.245 & .093 & -.53 \\
\hline & & Faure (1c & 3.77 & 26.0 & .085 & -.57 \\
\hline \multirow{6}{*}{ Amphibole } & & L. Alves (SC) & -- & -- & .130 & -.34 \\
\hline & Paragneiss & Curitiba (Pr) & -- & -- & .168 & -.14 \\
\hline & Amphibolit & São Roque & 2.33 & 7.10 & .199 & +.01 \\
\hline & Amphibolit & São Roque & 1.65 & 4.61 & .218 & +.11 \\
\hline & Amphibolit & São Roque & 1.33 & 4.00 & .202 & +.03 \\
\hline & & Faure (1988) & & & & \\
\hline \multirow{6}{*}{ Garnet } & Ggneiss & Itatins (SP) & 2.4 & 3.9 & .372 & +.89 \\
\hline & Gneiss & Curitiba (Pr) & -- & --- & .506 & +1.6 \\
\hline & Granite & Nazaré Paulista & 1.86 & 1.50 & .754 & +2.8 \\
\hline & Gneiss & Médio Coreau & 5.98 & 11.72 & 1.185 & +5.0 \\
\hline & Amphibolit & Pampeanas/Argentin & 2.11 & 6.40 & .199 & +.01 \\
\hline & & $\begin{array}{l}\text { a } \\
\text { Faure (1988) }\end{array}$ & 1.17 & 2.17 & .326 & +.66 \\
\hline \multirow[t]{2}{*}{ Allanite } & Granitoid & L. Alves (SC) & -- & -- & .0364 & -.82 \\
\hline & & Pimentel (1991) & 1750 & 23500 & .045 & -.77 \\
\hline \multirow[t]{2}{*}{ Monazite } & & & & & & \\
\hline & & Faure (1988) & 15000 & 88000 & .103 & -.48 \\
\hline Apatite & & Faure (1988) & 223 & 718 & .188 & -.04 \\
\hline Titanite & Grenitoid & $\begin{array}{l}\text { Pampeanas/Argentin } \\
\text { a }\end{array}$ & 590 & 2689 & .132 & -.33 \\
\hline
\end{tabular}

to be faster during the permobile tectonic regime.

Table 2 shows that the differences between TDM and TCHUR ages are practically close during the Archean, but began significantly deviate during the middle Paleoproterozoic. On the other hand, the differences between $\mathrm{T}_{\mathrm{CHUR}}$ model age (based on mantle chondritic) and the formation age $\left(\mathrm{T}_{\mathrm{Rb}-\mathrm{S}}\right)$ decreases considerably with geological time. The inflection after $2,2 \mathrm{Ga}$ shown in figure 2 and Table 2 can be related to an intense addition of material from upper mantle to the continental crust (Figs. 1 and 2), originating a major upper mantle depletion.

Fractionation factor $\left(\mathbf{f}_{\mathrm{SmNd}}\right)$ during geologic time The ${ }^{147} \mathrm{Sm} /{ }^{144} \mathrm{Nd}$ ratio for the great majority (about $80 \%$ ) of the granitoid rocks of the American South Platform changed between 0,09 to 0,125, corresponding to $\mathrm{af} \mathrm{f}_{14 \mathrm{mNd}}$ fractionation factor between $-0,35$ and $-0,60$ [where $\mathrm{f}_{\mathrm{SmNd}}={ }^{14 \mathrm{SmNd} /{ }^{144} \mathrm{Nd}}$ sample $-{ }^{147} \mathrm{Sm} /{ }^{144} \mathrm{Nd} \mathrm{CHUR}$ ) $/{ }^{147} \mathrm{Sm} /$ $\left.{ }^{44} \mathrm{Nd}_{\text {CHUR }}\right]$. Figure 3 shows the $\mathrm{f}_{\text {SmNd }}$ factor of TTG rocks as a function of geological time. The very small difference of $f_{S m N}$ suggests that the geochemical fractionation of Sm and $\mathrm{Nd}$ did not varied significantly during geological time. Such as observations can explain the relative parallelism of the $\mathrm{Nd}$ isotopic evolution lines shown in the figure 4 .

The certain constancy in the $\mathrm{Sm} / \mathrm{Nd}$ ratio for the granitoid rocks can be used to estimate the Sm-Nd model age (geological era), knowing only the ${ }^{143} \mathrm{Nd} /{ }^{144} \mathrm{Nd}$ ratio (Table 3 ).

When the $\mathrm{f}_{\mathrm{SmNd}}$ factor escapes of the $-0.45 \pm 0.10$ interval in granitoid rocks, we suggest that another chemical fractionation event of Sm-Nd would have taken place, possibly during partial melting of a crustal protholith previously recycled and enriched. In this case it will be necessary to use the $\mathrm{Nd}$ isotopic evolution model in double stage for the calculation of the $\mathrm{T}_{\mathrm{DM}}$ age.

To understand the behavior of the geochemical fractionation between $\mathrm{Sm}$ and $\mathrm{Nd}$ in total rock, Table 4 shows the estimated $\mathrm{f}_{\mathrm{Sm} / \mathrm{Nd}}$ values observed in the main rock minerals.

\section{The double stage equations for determination of the Sm-} Nd model ages ( $\mathbf{T}_{\mathrm{DM}}$ ) In rocks that have great amount of accessory minerals, such as to garnet or allanite, where the Sm fractionates very strongly in relation the $\mathrm{Nd}$ (Table 4), the single stage model ages would not have any geological meaning.

In cases where the $\mathrm{f}_{\mathrm{Sm} / \mathrm{Nd}}$ behaves incompatible with the single stage model, an alternative model should be searched (e.g.: double stage model), in the attempt to obtain compatible values with the regional geological history.

The mathematical equations for the double stage model has the following expression:

$$
\mathrm{T}_{\mathrm{DM}}=(1 / \lambda) \ln \left\{1+\left\{\mathrm{N}_{\mathrm{m}}-\left[\mathrm{N}_{\mathrm{c}}+\left(\mathrm{R}_{\mathrm{T} 1}-\mathrm{R}_{\mathrm{T} 2}\right)\left(\mathrm{e}^{\lambda \mathrm{T} 2}-1\right)\right]\right\} /\left(\mathrm{R}_{\mathrm{m}}-\mathrm{R}_{\mathrm{T} 1}\right)\right\}
$$

where, $\mathrm{N}_{\mathrm{C}}=\left({ }^{143} \mathrm{Nd} /{ }^{144} \mathrm{Nd}\right)=$ measured today in the crustal rocks, $\mathrm{N}_{\mathrm{m}}=\left({ }^{143} \mathrm{Nd} /{ }^{144} \mathrm{Nd}\right)=0,51315=$ depleted mantle, $\mathrm{R}_{\mathrm{T}}={ }^{147} \mathrm{Sm} /{ }^{144} \mathrm{Nd}$ $=$ measured today in the crustal rock, $\mathrm{R}_{\mathrm{T} 1}={ }^{147} \mathrm{Sm} /{ }^{142} \mathrm{Nd}=$ estimated value, $R_{m}=0,219=$ depleted mantle. $T_{1}=1^{\text {st. }}$ stage and $T_{2}=2^{\text {nd. }}$ stage (value corresponding to age of the secondary magmatic tectonic event). Constants $\mathrm{N}_{\mathrm{m}}$ and $\mathrm{R}_{\mathrm{m}}$ based in Millisenda et al. (1994).

The double stage ${ }^{143} \mathrm{Nd} /{ }^{144} \mathrm{Nd}$ evolution model as a function of the geological time can minimize the deviations caused by fractionation if the age of the $\mathrm{T}_{2}$ event and the ${ }^{147} \mathrm{Sm} /{ }^{144} \mathrm{Nd}\left(\mathrm{R}_{\mathrm{T} 1}\right)$ ratio are known. The $\mathrm{T}_{2}$ age can be estimated through $\mathrm{Sm} / \mathrm{Nd}$ isochron or other method such as $\mathrm{U}-\mathrm{Pb}$ in zircon concordia diagram, $\mathrm{Rb}-\mathrm{Sr}$ isochron, etc. The $\mathrm{R}_{\mathrm{T} 1}$ value can be estimated by the mean value of several determinations in similar rocks near the area. When Sm-Nd data are not available in similar terranes a mean $\mathrm{R}_{\mathrm{T} 1}$ of $0,11 \pm 0,01$ can be used for granitoids.

DePaolo and Schubert (1991) presented the calculation of Sm-Nd $\left(\mathrm{T}_{\mathrm{DM}}\right)$ model age model in double stage through the following expression:

$$
\mathrm{aT}^{2}+\mathrm{bT}+\mathrm{c}=0\left(\mathrm{~T}=\mathrm{T}_{\mathrm{DM}} \text { in } \mathrm{Ga}\right)
$$

where $\mathrm{a}=-2.0072 ; \mathrm{b}=-8.1725+2.0072 \mathrm{~T}_{2} ; \mathrm{c}=8.6+6.2725-\varepsilon_{\mathrm{Nd}}+$ $25.09 \mathrm{~T}_{2} \mathrm{f}_{\mathrm{Sm} / \mathrm{Nd} \text { (today) }}$ and $\mathrm{T}_{2}$ correspond to a crustal magmatic event.

The above constants is implicit the $\mathrm{f}_{\mathrm{Sm} / \mathrm{Nd} \text { (primary) }}$ value $(=-0.25$ $0.08 \mathrm{~T}_{\mathrm{DM}}$ ) of the primary event. The $\mathrm{f}_{\mathrm{Sm} / \mathrm{Nd}}$ was empirically deduced and, according to the authors, is subject to error.

Mafic-ultramafics rocks are not favorable to calculate of model ages, because they have very close ${ }^{147} \mathrm{Sm} /{ }^{144} \mathrm{Nd}$ ratios of the mantle. The $\mathrm{f}_{\mathrm{Sm} / \mathrm{Nd}}$ values oscillate between 0.35 to -0.35 . When $\mathrm{f}=0$ means that the sample has same $\mathrm{Sm} / \mathrm{Nd}$ ratio of the CHUR mantle. Therefore the $\mathrm{Nd}$ isotopic evolution line of such a sample will be parallel to that of the mantle. On the other hand, metaultra/mafic rocks they are in general favorable for isochronic dating method, due to their large variation of the ${ }^{147} \mathrm{Sm} /{ }^{144} \mathrm{Nd}$ ratio.

DISCUSSION Several Nd isotopic evolution exist in the upper mantle due to the complex history of tectonic and geochemical processes in the geological past. Rollinson (1993) present several of these models.

In the South American Platform, the weak depletion of the upper mantle during the Archean, but an intense depletion in the middle Paleoproterozoic between 2.2 - $1.9 \mathrm{Ga}$ reflects the intense differentiation of the upper mantle during formation of the continental crust during the latter. Nelson and DePaolo (1985) also observed such a fact in the Western of United States where a rapid growth of the continental crust occurred between 1.9 to $1.7 \mathrm{Ga}$.

Acknowledgements To Dr. Umberto G. Cordani and two referees of Revista Brasileira de Geociências for suggestions and discussions. 


\section{References}

Cordani U. G. and Sato K. 1999. Crustal evolution of the South American Platform, based on $\mathrm{Nd}$ isotopic systematics on granitoid rocks. Episodes 22:167-173

DePaolo D.J., Linn A.M., and Schubert G. 1991. The continental age distribution: method of determining mantle separation ages from Sm-Nd isotopic data and application to the southwestern United States. J. Geophys. Res., 96:2071-2088.

Faure G. 1988. Principles of Isotope Geology. ( $2^{\text {nd }}$ ed.) New York, John Wiley \& Sons. 589.

Nelson B. K. and DePaolo D. J. 1985. Rapid production of continental crust 1.7 to 1.9 b.y. ago: Nd isotopic evidence from the basement of the North American mid-continent. Geol. Soc. Am. Bul. 96:746-754.

Millisenda C.C., Liew T.C., Hofmann A.W., and Köhler H. 1994. Nd isotopic mapping of the Sri Lanka basement: update and additional constraints from $\mathrm{Sr}$ isotopes.

Pachett P.J. 1992. Isotopic studies of Proterozoic crustal growth and evolution. In: K.C. Condie (ed.). Proterozoic crustal evolution. Elsevier. p484-508.

Pimentel M.M. and Charnley N. 1991. Intracrustal REE fractionation and implication for Sm-Nd model age calculations in late stage granitic rocks.: An example from central Brazil. Chem. Geol. 186:123-138.
Rollinson H.R. 1993. Using geochemical data: evolution, presentation, interpretation. Longman Scientific \& Technical. p215-343

Sato K. 1998. Evolução Crustal da Plataforma Sul Americana, com base na geoquímica isotópica Sm-Nd. PhD thesis. São Paulo University, Brazil, 300pg.

Sato K. 1999. Superproduction evidence of the continental crust during Paleoproterozoic in South American Platform.. II South American Symposiun on Isotope Geology. Extend Abstract, p361-362.

Sato K., and Siga Jr. O. 2000. Crustal evolution of the Southern South American Platform and Cenrtral Portion of the Patagonian, based on Sm-Nd isotopic data. $31^{\text {st }}$ International Geological Congress - Abstract.

Santos Ticiano J. S. 1999. Evolução Tectônica e Geocronológica do Extremo Noroeste da Província Borborema. PhD Thesis. Inst. de Geociências, UNESP, Rio Claro, 195pg.

Contribution IGC-147

Received march 3, 2000 Accepted for publication march 30, 2000 